\title{
Changes in foliage's biomass of two-needled pine subgenus (Pinus spp.) and genus Betula spp. along the gradients of winter temperature and precipitation: inter-genera paradox in the forests of Eurasia
}

\author{
Vladimir Andreevich Usoltsev \\ Russian academy of science

\section{Baozhang Chen} \\ Chinese Academy of Sciences \\ Seyed Omid Reza Shobairi ( $\sim$ omidshobeyri214@gmail.com ) \\ Ural State Forestry Engineering University https://orcid.org/0000-0002-6528-8653 \\ Ivan Stepanovich Tsepordey \\ Russian academy of science

\section{Shoaib Ahmad Anees} \\ Beijing Forestry University
}

\section{Research}

Keywords: hydrothermal gradients, foliage biomass, foliage efficiency, regression models, biomass equations, mean January temperature, annual precipitation, principle of limiting factors by Liebig-Shelford

Posted Date: September 17th, 2020

DOI: https://doi.org/10.21203/rs.3.rs-71384/v1

License: (1) This work is licensed under a Creative Commons Attribution 4.0 International License. Read Full License 


\section{Abstract \\ Background}

The main pool of publications on this topic is related to the assessment of possible changes in vegetation growth under the influence of climate, but few of them actually took account the impacts of global change on species composition and morphological (taxational) structure, so led to an unanswered question, how the biological productivity of the forests will change if air temperature and/or precipitation change up to a certain extent. This is a subject of the study.

\section{Methods}

In this study, our database is used in a number of 2,110 sample plots for pine and 510 for birch. In each sample plot, the biomass of the forest stands was positioned in maps of January mean temperature isolines and to mean annual precipitation ones, and the input data matrix was compiled in which the values of biomass components and of stand taxation characteristics are mated with corresponding values of climate indices. The matrix was then subjected to regression analysis.

\section{Results}

It is stated, in cold and insufficiently moisture-rich climate zones, temperature increase causes a decrease in biomass of Pinus foliage, and in other regions its increase, but the Betula pattern is the opposite. With an increase in precipitation, the Pinus foliage biomass in warm zones increase, and in cold ones it decreases, but the Betula pattern is the opposite.

\section{Conclusion}

The biomass of pine and birch stands change in gradients of winter temperature and precipitation as propeller-formed but opposite patterns, which can be explained by the different winter physiology of evergreen and deciduous species.

\section{Introduction}

In recent decades, numerous world-wide studies have proved that the irreversible climate change would result in biota catastrophe and a problem with the survival of mankind (Emanuel et al., 1985, Toman et al., 1996, Behrensmeyer, 2006, Halofsky et al., 2018, Kosanic et al., 2018, Miles-Novelo and Anderson, 2019, Xu et al., 2020). The main pool of publications on this topic is related to the assessment of possible changes in vegetation growth under the influence of climate, but few of them actually took account the impacts of global change on species composition and morphological (taxational) structure, so led to an unanswered question, how the biological productivity of the forests will change if air temperature and/or precipitation change up to a certain extent (Anderson et al., 2006, Keeling and Phillips, 2007, Eggers et al., 2008, Huston and Wolverton, 2009, Shuman, Shugart, 2009, Poudel et al., 2011, Han et al., 2018, Zeller et al. 2018), and how these altered forests will affect the gas composition of the atmosphere changed due to climate shifts. In other words, we are dealing with a typical rigid feedback scheme that is common to all complex biological systems (Abramova, 1968, P. 169).

Long before Charles Darwin, Russian academician Ivan Lepekhin proposed the idea of changing the properties of plants and animals under the influence of environmental changes. In the descriptions of his expedition across the Ural Mountains in Russia, he noted: "Plants and animals can get used to different climates and, depending on the habitat conditions, they can acquire properties that make their behavior reborn" (Lepekhin, 1780. P. 93). Though there is the common agreement that vegetation responses to climate change are species-specific (Schulze \& Mooney, 1994, Spathelf et al., 2018), how the biological production of stands for certain tree species (genera) would be impacted in the Trans-Eurasian climatic gradients of temperature and precipitation is unknown, because the available regional information is fragmentary and contradictory (Strömgren, Linder, 2002, Wilmking et al., 2004, Huang et al. 2010, Stegen et al., 2011, Fu et al., 2017, Forrester et al. 2017). 
It was reported that in Canada the temperature of January and humidity conditions had a positive effect on the growth of Betula papyrifera, and the growth of Picea mariana was positively affected by the winter and spring temperatures in the current year (Huang et al. 2010). High temperature and precipitation in growth season could depict positive impact on tree biomass (Zhou et al. 2008). Furthermore, extra sugar is stored in winter tree, which will be available for tree growth till next summer (LaMarche 1974). The dendroclimatological analyses showed that the positive moisture balance in current April and previous September was the dominant climatic factor favoring the radial growth of Quercus cerris in Albania (Stafasani, and Toromani, 2015). Some discrepancies in the regional responses of the studied species mean that regional patterns of stand productivity may be not necessarily extrapolated to the transcontinental level (Huang et al. 2010).

The dependence of the radial growth of European spruce, Scots pine and European beech trees on the climate and water balance of the soil was studied using data from 24 sample plots in Germany for the period from 1951 to 2006 . By combining the obtained models with climate forecast data published by the IPCC expert group for the period up to 2100, a forecast of the dynamics of growth of three tree species up to 2100 is made. It turned out that for spruce, environmental conditions become more and more unfavorable over time, which leads to a gradual decrease in growth. For Scots pine and for beech, the negative effect on radial growth of simulated climate scenarios and soil water balance could not be detected until 2100 (Röhle et al. 2010). All of the above uncertain and contradictory patterns indicate that the results obtained were not reproducible. The lack of reproducibility of scientific results is a critical feature of modern science (loannidis 2005). A special study found that more than $70 \%$ of researchers tried and failed to reproduce the experiments of another scientist, and more than half of them failed to reproduce their own experiments (Baker 2016). At the same time, the limits of reproducibility in science are discussed (Guttinger 2020).

A paradoxical conclusion was reached in Russian Siberia with respect to forest cover (Lapenis et al., 2005), where with a warming climate and a simultaneous decrease in precipitation, the share of assimilation mass decreases, and the share of wood components increases. Even more, it was found that in pure forest stands, net primary production reacts to temperature increases in different climatic zones in different ways: it increases in temperate forests, remains stable in boreal forests, and decreases in wet forests in the Mediterranean, but as the biodiversity index increases, different zonal trends gradually transform into a common, unified negative trend. These patterns do not yet find any biological or ecological explanation (Paquette et al., 2018). In comparison with these uncertainties and contradictions, we obtained a much more surprising and paradoxical result when studying changes in the biomass of pine and birch foliage in the hydrothermal gradients of Eurasia, which is described in this article.

The two-needled subgenus (Pinus spp.) (the diploxylon, or hard pines) is divided into the predominantly Eurasian and Mediterranean section Pinus, composed of subsections Pinus and Pinaster, includes about 100 species spread in boreal and mid-latitude zones and also in the mountain regions of the subtropical zone of the northern Hemisphere (Gernandt et al., 2005). There are about 10 species in Russia. Of the two-needled pines, the Scots pine (Pinus sy/vestris L.) is the most common in Eurasia and among conifers only larches occupy a bigger area than pines. This is a large evergreen whorlbranching light-demanding tree with a transparent crown. Its needle foliage is adapted to conservative water consumption, tolerates temperatures of $-50^{\circ} \mathrm{C}$ to $+50^{\circ} \mathrm{C}$ and lives for $5-6$ years long. At the Northern limit of Eurasia, its growth is limited by a small crop of cones and very low seed quality (Boychenko, 1970). The bark is thick, scaly dark grey-brown on the lower trunk, and thin, flaky and orange on the upper trunk and branches (Bobrov, 1978, Mamaev, 1983).

Birch belongs to Betulaceae family. This family has 120-150 species (Grimm and Renner 2013). Majority of species are present in northern zones and have a wide natural distribution area on the Eurasian continent, ranging from the Atlantic to eastern Siberia. Genus Betula spp. is among ten common species in Russia, and 40 its species are presented in Russia. It plays an important ecological role in the formation of woody vegetation throughout the Quaternary period (Denisov, 2002), and in dry steppe conditions with high ground water forms pure stands that are resistant to droughts (Perov, 2008). There are several species in the common birch category from the section Albae Rgl.: silver birch (B. pendula Roth.), downy birch ( $B$. pubescens Ehrh.), mountain birch (B. tortuosa Ldb.) and Japanese white birch (B. platyphylla Sukacz.) (Hynynen et al. 2009, Usoltsev, 2019). 
To reduce the uncertainty results mentioned above, a transcontinental level of analysis was chosen in our study. The purpose of this study was to show how much the foliage biomass of the light-coniferous subgenus Pinus spp. can change with a possible increase in temperature by $1{ }^{\circ} \mathrm{C}$ at constant precipitation and with a possible increase in precipitation by $100 \mathrm{~mm}$ per year at constant temperature, and to compare the results with similar data for small-leaved genus Betula spp. in Eurasia. Since the productive and carbon-deposing potential of a plant community is determined by the biomass of assimilating organs, we have focused in this article not on the total biomass of forest stands, but only on the mass of foliage.

\section{Material And Methods}

The database used in this study involves 3,020 sample plots with Pinus and 650 sample plots with Betula stand biomass in tons per hectares, including both pure stands and stands with admixture of other species (Usoltsev 2020). Since the response to climate change differs between pure and mixed stands (Paquette et al., 2018), in our comparative study we used harvest data only from pure stands that were selected from our database in a number of 2,110 sample plots for pine and 510 for birch. Subgenus Pinus sp. is presented in $86 \%$ by Scots pine (Pinus sy/vestris L.) and in smaller quantities by the following species: P. tabuliformis Carr. P. densiflora S. et Z., P. nigra Arn., P. pinaster Aiton, $P$. brutia var. pityusa (Steven) Silba, and $P$. thunbergii Parl. Of the 650 sample plots for Betula, about $80 \%$ are presented by white birches, i.e. silver birch (Betula pendula Roth) and downy birch (Betula pubescens Ehrh.) We are not able to distinguish in our database these two types of birch forests, differing in their ecology and possibly in their response to climate change (Hynynen et al. 2010). However, they are very adaptive to changes in their growth environment (Laitakari 1935, Köstler et al. 1968, Ostonen et al. 2007).

In most cases, sample trees were taken on each of sample plots in a number from 5 to 10 copies. Then samples were taken from each biomass component to determine the dry matter content (and for wood and bark of stems also to determine the basic density) after drying the samples at the temperature of $80-100^{\circ} \mathrm{C}$. The quantity of each biomass component per 1 ha was determined by regression method. Nevertheless, some sampling procedures for estimating biomass of tree components differed between the studies, since they were performed by representatives of different scientific fields in forestry. The locations of sampling sites are shown in Fig. 1. We can see that despite the different number of sample plots for Pinus and Betula, the coverage of the territory of Eurasia by these genera is approximately the same.

In each sample plot, the biomass of the forest stands was positioned in accordance to January mean temperature isolines and to mean annual precipitation ones, and the input data matrix was compiled in which the values of biomass components and of stand taxation characteristics are mated with corresponding values of mean January temperature and precipitation taken from World Weather Maps (2007). The matrix was then subjected to regression analysis.

The question may arise why modelling was performed at a level of genera, and not for individual pine and birch species. If we adhere to the concept of species-specific responses of forest biomass to changes in the main climatic characteristics, then when we reach the transcontinental level, we are faced with the obvious fact that no species grows throughout the continent, precisely because of regional climate differences. Moving from refuges under the influence of geological processes and climate changes, the particular species adapted to changing environmental conditions, forming a series of vicariate species within a genus (Hultén 1937, Tolmachev 1962, Chernyshev 1974). This gives grounds for analyzing the response of tree species to changes in climate characteristics, to combine them into one climate-dependent set within the entire genus, since differences in ecological and physiological properties of different species of the genus, for example, Betula pendula Roth vs. B. utilis D. Don vs. B. maximowicziana Regel are derived from regional climatic features.

It is well known that when estimating stem biomass growth by using the annual ring width, the greatest contribution to explaining its variability being made by summer temperature. Moreover, it was established that this relationship is positive with the maximum intra-annual temperature and negative with the minimum and average annual temperature (Khan et al. 2019). With an inter-annual time step, the predominant influence of summer temperature is quite normal (Levanič et al., 2015, Zubairov et al., 2018, Bocharnikov, 2019). But against the background of long-term climatic shifts for decades, the prevailing influence is acquired by winter temperatures (Toromani, Bojaxhi, 2010, Bijak, 2010, Morley et al., 2017), having in mind that 
winter air temperatures in the Northern hemisphere were increased faster than in summer during the 20th century (Emanuel et al., 1985, Folland et al., 2001, Laing and Binyamin, 2013, Felton et al., 2016). This phenomenon may be associated with the shift of the earth's magnetic pole towards Siberia (Olsen and Mandea 2007).

In terms of regression analysis, a weak temporal trend of summer temperatures compared to a steep trend of winter ones means a smaller regression slope and a worse ratio of residual variance to the total variance explained by this regression. Obviously, taking the mean winter temperature as one of the independent variables, we get a more reliable dependence having the higher predictive ability. To ensure the maximum stability of the model, each of the selected factors (independent variables) should be presented in the maximum range of its variation (Usoltsev 2003). In our example, mean January temperatures ranged from $-40{ }^{\circ} \mathrm{C}$ in the forest-tundra of the North-Eastern Siberia to $+10{ }^{\circ} \mathrm{C}$ in the subtropics of China. We compiled precipitation data ranging from $190 \mathrm{~mm}$ in permafrost regions of North-Eastern Siberia to 1,140 mm in South of China and to 2,500 in Greenland.

The matrix was used as a source of data (their fragment one can see in Table 1 ) in the subsequent regression analysis. It is well known that the biomass of a stand represented by a particular tree species is primarily determined by its age and morphological (taxation) structure, i.e., a set of characteristics such as age, mean height, mean diameter at breast height, the basal area, and the volume stock, which are interrelated. The problem of multi co-linearity arises in empirical modeling of biomass. One of the solutions to the problem is to harmonize the system by constructing recursive (recurrent, related) equations for the different mensuration indices and foliage biomass, in which the dependent variable of the previous equation is included as one of the independent variables of the subsequent one (Draper and Smith 1966). This approach as one of the methods for model harmonization (Jacobs and Cunia 1980), provides a multivariate conditionality of factors that provide flexibility and universality of the regression system describing the dynamics of biomass of stands. 
Table 1

A fragment of the original matrix of experimental data *

\section{Pine forests}

A $\quad \mathrm{N}$

$\mathrm{N}$

A

$20 \quad 2.275 \quad 15$

$\begin{array}{lll}25 & 3.838 \quad 50\end{array}$

25

23

31

35

55

18

28

80

100

120

13

20

20

22

32

30

26

25

35

28

\begin{tabular}{|ll}
\hline 20 & 2.275 \\
\hline 25 & 3.838 \\
\hline 25 & 4.516 \\
\hline 23 & 3.640 \\
\hline 31 & 2.370 \\
\hline 35 & 1.890 \\
\hline 55 & 0.760 \\
\hline 18 & 5.189 \\
\hline 28 & 3.608 \\
\hline 80 & 0.528 \\
\hline 100 & 0.349 \\
\hline 120 & 0.258 \\
\hline 13 & 82.40 \\
\hline 20 & 44.43 \\
\hline 20 & 19.76 \\
\hline 22 & 43.81 \\
\hline 32 & 19.91 \\
\hline 30 & 1.475 \\
\hline 26 & 2.543 \\
\hline 25 & 1.533 \\
\hline 35 & 2.104 \\
\hline 28 & 0.542 \\
\hline 32 & 0.546 \\
\hline 28 & 0.540 \\
\hline 50 & 0.101 \\
\hline 50 & 0.389 \\
\hline 110 & 0.091 \\
\hline 5
\end{tabular}

32

28

50

50

110

100

210

$\begin{array}{lll}0.661 & 144 & 2.70 \\ 0.722 & 190 & 1.6\end{array}$

* Designations here and further: $A=$ stand age, yrs; $V=$ stem volume, $\mathrm{m}^{3} / \mathrm{ha} ; N=$ tree density, 1000
biomass, t per ha; $T m=$ mean January temperature, ${ }^{\circ} \mathrm{C} ; P R m=$ mean annual precipitation, $\mathrm{mm}$. 


\begin{tabular}{|llllllllllll|}
\hline \multicolumn{1}{|l}{ Pine forests } \\
\hline 25 & 1.329 & 88 & 5.2 & -5 & 570 & 50 & 0.755 & 234 & 6.68 & -5 & 570 \\
\hline 29 & 1.707 & 169 & 6.6 & -5 & 570 & 57 & 0.637 & 268 & 1.51 & -5 & 570 \\
18 & 36.93 & 93.2 & 6.3 & 0 & 890 & 43 & 0.900 & 131 & 1.48 & -5 & 890 \\
\hline
\end{tabular}

As for choosing the structure of the regression model, we adhered to the concept that there is only one definite variant of stand biomass structure corresponding to a given structure of taxonomic parameters (morphological structure) of a tree stand (Usoltsev 2007). The initial structure of the model included the main mass-forming indices of stands - age, stem volume, tree density, mean diameter and mean height. Mean diameter, and mean height were excluded in the process of the regression analysis as these factors were not statistically significant. The synergism $(\ln A) \cdot(\ln N)$ was introduced in the model to account for the decrease in the tree density with age and its effect on the foliage biomass. The final structure of the model included only those mass-forming indices that were statistically significant for foliage biomass component.

\section{Results}

The matrix was used as a source of data in the subsequent regression analysis, and after correcting on logarithmic transformation by G.L. Baskerville (1972), the recursive equations for the mensuration indices and foliage biomass were derived:

$\ln N=\mathrm{f}\{\ln A, \ln (T m+\mathrm{M}), \ln P R m,[\ln (T m+\mathrm{M})] \cdot(\ln P R m)\} \rightarrow$

$\rightarrow \ln V=\mathrm{f}[\ln A, \ln N,(\ln A)(\ln M), \ln (T m+\mathrm{M}), \ln P R m,[\ln (T m+\mathrm{M})] \cdot(\ln P R m)\} \rightarrow$

$\rightarrow \ln P i=\mathrm{f}\{\ln A, \ln V, \ln N,(\ln A)(\ln M), \ln (T m+\mathrm{M}), \ln P R m,[\ln (T m+\mathrm{M})] \cdot(\ln P R m)\} .(1)$

Equation (1) for foliage biomass is presented in Table 2. Because mean January temperature in northern part of Eurasia has negative values, the corresponding independent variable was increased by $\mathrm{M}(T m+\mathrm{M})$ to enable a logarithmic transformation according to (Baskerville 1972), where $M=40$ for Pinus and $M=50$ for Betula. All the necessary calculations were carried out in Stat graphics software (http://www.statgraphics.com/). First of all, we should pay attention to the signs for climate variables in the equations for pine and birch (Table 2). In the equations for the foliage biomass, the regression coefficients for the variables: temperature, precipitation and their combined effect (synergy) are equal to $-3.6140,-1.6842$ and +0.5555 for pine and $+8.2177,+4.3173$ and -1.2789 for birch, correspondingly, i.e. we have mirror patterns for the foliage biomass of pine and birch. These regression coefficients are significant at the probability level of 0.9999 , and the corresponding values of $t$-Student are $-6.20,-5.31$, and +6.03 for pine foliage, and $+4.87,+4.33$, and -4.68 for birch foliage. 
Table 2

Characteristic of equations (1) for forest stands of the Pinus, and Betula in Eurasia

\begin{tabular}{|c|c|c|c|c|c|c|c|c|c|c|}
\hline $\ln \left(Y^{(1)}\right.$ & $a_{0}^{(2)}$ & $\ln A$ & $\ln V$ & $\ln N$ & $(\ln A) \cdot(\ln N)$ & $\begin{array}{l}\ln (T m \\
+\mathrm{M})\end{array}$ & In $P R m$ & $\begin{array}{l}{[\ln (T m+} \\
M)] \cdot(\ln P R m)\end{array}$ & $\operatorname{adj} R^{2(3)}$ & $\mathrm{SE}^{(4)}$ \\
\hline \multicolumn{11}{|l|}{ Pinus } \\
\hline $\ln (N)$ & 2.8168 & -1.0696 & - & - & - & 1.9165 & 0.5011 & -0.3577 & 0.566 & 0.72 \\
\hline $\ln (V)$ & 16.4304 & 0.7200 & - & -0.7996 & 0.2065 & -3.3579 & -2.5007 & 0.6225 & 0.472 & 0.69 \\
\hline $\ln (P f)$ & 11.8492 & -0.3495 & 0.4313 & 0.1311 & -0.0289 & -3.6140 & -1.6842 & 0.5555 & 0.424 & 0.36 \\
\hline \multicolumn{11}{|l|}{ Betula } \\
\hline $\ln (N)$ & -14.3298 & $\overline{1.7556}$ & - & - & - & 4.9674 & 4.1687 & -0.9833 & 0.715 & 0.75 \\
\hline $\ln (V)$ & -26.8621 & 0.7441 & - & -0.4407 & 0.1195 & 8.0501 & 4.4803 & -1.2297 & 0.707 & 0.47 \\
\hline $\ln (P f)$ & -29.6226 & -0.0321 & 0.5605 & 0.2644 & -0.0287 & 8.2177 & 4.3173 & -1.2789 & 0.425 & 0.42 \\
\hline \multicolumn{11}{|c|}{ Designations for Table 1: } \\
\hline
\end{tabular}

The proportions of the contribution of independent variables to the explanation of the variability of the forest biomass in equations (1) are shown in Table 3 . We can see that mass-forming variables explain in averaged about 78 , and $61 \%$ of the variability of foliage biomass in Pinus, and Betula correspondingly, including 47, and $39 \%$ of the contribution from the stem volume. Climate variables explain about 22, and $39 \%$ of the foliage biomass variability in Pinus, and Betula correspondingly, i.e. less than about 3.5, and 1.6 times as much as mass-forming variables in Pinus, and Betula correspondingly.

Table 3

Contribution of independent variables of equations (1) to the explanation of variability of dependent variables, $\%$

\begin{tabular}{|c|c|c|c|c|c|c|c|c|c|}
\hline \multirow[t]{2}{*}{$\ln (Y)$} & \multicolumn{9}{|c|}{ Independent variables } \\
\hline & $\ln A(I)$ & $\ln V(I I)$ & $\ln N(I I I)$ & $(\ln A) \cdot(\ln N)$ & $\begin{array}{l}I+I I+I I I \\
+I V\end{array}$ & $\ln (T m+M)$ & $\begin{array}{l}\ln P R m \\
(\mathrm{VI})\end{array}$ & $\begin{array}{l}{[\ln (\operatorname{Tm}+} \\
\mathrm{M})] \cdot(\ln P R m)(\mathrm{VII})\end{array}$ & $\begin{array}{l}\mathrm{V}+\mathrm{VI}+ \\
\mathrm{VII}\end{array}$ \\
\hline \multicolumn{10}{|l|}{ Pinus } \\
\hline $\ln (P f)$ & 22.4 & 47.3 & 4.3 & 3.6 & 77.6 & 7.9 & 6.8 & 7.7 & 22.4 \\
\hline \multicolumn{10}{|c|}{ Betula } \\
\hline $\ln (P f)$ & 1.5 & 38.6 & 15.0 & 5.5 & 60.6 & 13.8 & 12.3 & 13.3 & 39.4 \\
\hline
\end{tabular}

The recursive system of Eq. (1) was tabulated in the sequence indicated by the arrows as follows: first, the values of tree density according to the given values of age, temperature and precipitation were obtained, then the volume stock according to the given values of age, temperature and rainfall and the calculated values of the tree density were obtained, and finally, the values of the foliage biomass according to the given values of age, temperature and precipitation, the calculated values of tree density and the volume stock were obtained. From the resulting tables, the values of the foliage biomass for the age of maturity (100 years for pine and 50 years for birch) are taken, and 3-D graphs showing statistically significant transcontinental trends of biomass in temperature and precipitation gradients are designed (Fig. 2).

\section{Discussion}


We can see in Fig. 2 that there are two patterns of significantly differential changes in the pine and birch foliage biomass in precipitation and winter temperature gradients in the form of two oppositely directed propellers. The most interesting question is how much the foliage biomass would change with an air temperature deviation from the usual norm, for example, by $1^{\circ} \mathrm{C}$ and with a precipitation deviation from the usual norm, or by $100 \mathrm{~mm}$ per year. The constructed models give us the answer to such question in relation to pine and birch stands. To do this, we took the first derivative of 3-Dimensional surfaces (Fig. 2), and not analytically, but graphically, i.e. we took off the biomass difference interval $(\Delta, \% \%)$ corresponding to temperature interval $1{ }^{\circ} \mathrm{C}$ and precipitation interval $100 \mathrm{~mm}$ directly from the graphs or from the corresponding tables, and get the answer in the form of 3-Dimensional surfaces divided into plus and minus areas that correspond to the increase or decrease in the biomass of stands having the age of 100 years for Pinus (Fig. 2a) and 50 years for Betula (Fig. 2b). It is assumed that climate change does not affect precipitation, which changes only geographically (by ecoregions), while as a result of the expected climate change the temperature increases by $1{ }^{\circ} \mathrm{C}$ at different territorial (zonal) temperature levels, designated as $-30 \Delta(-40 \Delta)$ $\ldots+10 \Delta(0 \Delta)$. It is also assumed that climate change does not affect temperatures, which change only geographically (by ecoregions), while as a result of expected climate change, annual precipitation increases by $100 \mathrm{~mm}$ at various territorial precipitation levels, designated as $300 \Delta \ldots 900 \Delta$.

Figure 3a shows the change in Pinus foliage biomass $(\Delta, \%)$ with a temperature increase of $1{ }^{\circ} \mathrm{C}$ in different ecoregions characterized by different temperature and precipitation ratios. Thus, Fig. 3a demonstrates a common pattern in Pinus of the Eurasian scale: in cold $\left(\mathrm{Tm}=-30^{\circ} \mathrm{C}\right)$ and insufficiently moisture-rich $(P R m=300-400 \mathrm{~mm})$ climate zones, temperature increase with constant precipitation causes a decrease in biomass of foliage (the location of the increment surface below the zero plane), and in other regions - its increase (the location of the increment surface above the zero plane). In the contrary, Fig. $3 \mathrm{~b}$ demonstrates a common pattern in Betula of the Eurasian scale: in cold $\left(\mathrm{Tm}=-30^{\circ} \mathrm{C}\right)$ and insufficiently moisture-rich $(P R m=300-400 \mathrm{~mm})$ climate zones, temperature increase with constant precipitation causes an increase in biomass of foliage (the location of the increment surface above the zero plane), and in other regions - its decrease (the location of the increment surface below the zero plane).

Figure 4a shows the change $(\Delta, \%)$ in the Pinus foliage biomass with an increase in precipitation of $100 \mathrm{~mm}$ in different ecoregions. In warm zones $\left(0^{\circ} \mathrm{C}\right.$ to $\left.10^{\circ} \mathrm{C}\right)$, with an increase in precipitation of $100 \mathrm{~mm}$, foliage biomass increase (the location of the increment surface above the zero plane), and in cold ones $\left(\nabla 20^{\circ} \mathrm{C}\right.$ to $₫ 30{ }^{\circ} \mathrm{C}$ ) it decreases (the location of the increment surface under the zero plane). In contrary, Fig. $4 \mathrm{~b}$ demonstrates a common pattern in Betula of the Eurasian scale: in cold ( $T_{m}$ $\left.=-40{ }^{\circ} \mathrm{C}\right)$ and insufficiently moisture-rich $\left(P R_{m}=300-400 \mathrm{~mm}\right)$ climate zones, temperature increase with a constant precipitation causes an increase in foliage biomass (the location of the increment surface above the zero plane), and in other regions - its decrease (the location of the increment surface below the zero plane).

We can see in Fig. 2a, that pine forests show a monotonous increase in foliage biomass in the gradient of temperature increase but only when there is sufficient water supply $\left(P R_{m}=900 \mathrm{~mm}\right)$, and as the transition from moist areas $\left(P R_{m}=\right.$ $900 \mathrm{~mm}$ ) to areas of nonsufficient water supply $\left(P R_{m}=300 \mathrm{~mm}\right)$, the trend changes to the opposite (Fig. 2a). In the gradient of increasing precipitation, pine forests show a monotonous increase in foliage biomass but only in cold areas $\left(\mathrm{Tm}=-30{ }^{\circ} \mathrm{C}\right)$, and as the transition from cold areas to warm ones $\left(\operatorname{Tm}=10^{\circ} \mathrm{C}\right.$ ), the trend changes to the opposite (Fig. 2a). A similar general pattern was observed earlier at the local level in the marsh forests of Siberia, where at the maximum amounts of temperature sums above $10^{\circ} \mathrm{C}\left(2200^{\circ} \mathrm{C}\right)$ there is an increase in the radial growth of stems by $30-50 \%$ with an increase in precipitation from 400 to $600 \mathrm{~mm}$, and at the minimum amounts of temperature sums $\left(1600{ }^{\circ} \mathrm{C}\right)$ the radial growth is reduced by $4-9 \%$ with an increase in precipitation in the same range. Correspondingly, at the level of precipitation of $400 \mathrm{~mm}$ the radial growth is reduced by $14-20 \%$ with an increase in the sum of temperatures from 1600 to $2200{ }^{\circ} \mathrm{C}$, and it increases by $14-33 \%$ in the same temperature range at the level of precipitation of $600 \mathrm{~mm}$ (Glebov and Litvinenko, 1976). According to the results obtained by Molchanov (1976), in the North of Eurasia the greatest influence on the growth of the annual tree ring is the air temperature, and in the conditions of the southern forest-steppe the dominant role is played by precipitation.

It is well known the Liebig's law of the minimum (1840), according to which a growth rate depends on the factor that is at the minimum in relation to its needs. Although J. Liebig, followed by J. Esslen (1905), had shown that a limiting factor can be not 
only a lack, but also an excess of such factors as light, heat and moisture (a lot of "good" is also "not good"), nevertheless, he focused his attention mainly on the effect of the minimum of chemicals (oxygen, phosphorus, boron, etc.), and as a result of that, this phenomenon was established in science as the law (principle) of the minimum by Liebig. The idea of the limiting influence of the maximum on a par with the minimum was developed by V. Shelford (1913), who extended the limiting principle to any environmental factors and became known as the author of Shelford's law of tolerance. W.P. Taylor (1934) followed the same concept. Later A.A. Molchanov (1971) interpreted the limiting principle in relation to forest ecosystems as an "extended concept of limiting factors", according to which "any state approaching or exceeding the limit of resistance for any organism and groups of interest can be considered as a limiting factor" (p. 271). Recently, this phenomenon has be-come widespread as the principle of limiting factors by Liebig-Shelford (Rozenberg et al., 2016). The reaction of pine foliage biomass (Fig. 2) on temperature and precipitation corresponds to the principle by Liebig-Shelford: since the minimum values of biomass occur in regions with minimum precipitation $(P R m=300 \mathrm{~mm})$ in warm climate and minimum temperature $\left(T_{m}=\right.$ $-30^{\circ} \mathrm{C}$ ) with sufficient water supply, these two factors are limiting in relation to pine foliage biomass.

At the same time, birch demonstrates the opposite 3-D pattern under the same conditions, i.e. the minimum values of biomass occur in regions with minimum precipitation $\left(P R_{m}=300 \mathrm{~mm}\right)$ in warm climate and minimum temperature $\left(-40{ }^{\circ} \mathrm{C}\right)$ with nonsufficient water supply. As we can see from Fig. 1, the areas of the sample areas distribution in Eurasia are approximately the same, and therefore the presented temperature and precipitation ranges for pines and birches are the same, and, consequently, the limits of applicability of the models for pines and birches are the same. However, the biomass of birch stands in the database is 4 times less than that of pine, but even if we equalize the harvest data pools for pines and birches, the limits of applicability of the models will not change, and, of course, this will not lead to a change of signs in birches for independent variables - temperatures, precipitation, and their synergy. Then what can be the reason for the opposite trends in foliage biomass in pine and birch, which are statistically significant probability level reaches 0.9999 , i.e. $p$-value $<0.00001$.

Let us try to link the obtained counterintuitive patterns of changes in foliage biomass with previously published TransEurasian trends in foliage productivity as the ratio of annual growth in the stem volume or aboveground biomass to the biomass of the assimilation apparatus. It is known as foliage efficiency (FE) (Usoltsev et al., 2018). It was found that in the direction from the northern moderate zonal belt to the subequatorial one, FE increases in pine and decreases in birch in the same zonal range. This phenomenon seems to be related to the fundamental difference between the winter physiology of evergreen and deciduous species, namely the ability of the former to assimilate atmospheric carbon dioxide and prolong the assimilation process beyond the vegetation period, which is usual for deciduous species (Jumelle, 1892, Ewart, 1896, Matthaei, 1902, Henrici, 1921, Iwanoff, Kossowitsch, 1929, Zacharowa, 1929, Ivanov \& Orlova 1931, Printz, 1933, Cartellieri, 1935, Ålvik, 1939, Freeland, 1944, Zeller, 1951, Pisek, Rehner, 1958, Pisek, 1960, Lyr et al. 1974, Kramer \& Kozlovsky 1983, Schaberg et al., 1995, Wieser, 1997, Smashevskiy, 2014).

In pine trees in the southern direction, due to higher winter temperatures, the winter accumulation of assimilates increases as a result of excess of photosynthesis over respiration, which is associated with the autumn-winter litter fall of foliage (Zalesov, et al., 1994), which apparently determines the trend of increasing FE in the direction from the northern temperate zone to the subequatorial one.

In birch trees, FE in the direction from the northern temperate to the subequatorial zone does not increase, as in pine, but decreases, possibly due to an increase in the respiration losses during a shorter physiologically active period (due to leaf shedding) compared to pine. In essence, everything depends on the ratio of photosynthesis and respiration in the pine, especially during the period when the birch does not have photosynthesis, but only respiration. If we assume the presence of a positive ratio of foliage biomass and FE, then in our case, the opposite FE trends of two species coincide with opposite trends in foliage biomass, but only in regions of sufficient moisture $(P R m=800-900 \mathrm{~mm})$ (Fig. 2a, b), and as we move to areas of insufficient moisture $\left(P R_{m}=300 \mathrm{~mm}\right)$, this coincidence is replaced by a complete contradiction.

The differences between pine and birch in FE values are also apparent as the climate continentality (summer aridity of the climate) increases: FE decreases most intensively in pine forests, and significantly less intensively in birch communities. As

Page 10/19 
the continentality index by Khromov (1957) increases from 55 to 95\%, the FE in pine decreases by 8 times, and in birch the corresponding decrease in FE is less than $2 \%$. The decrease in foliage biomass coincides with the decrease in FE as the climate increases in aridity only in pine trees and only in warm regions $\left(T_{m}=0\right.$ to $\left.10{ }^{\circ} \mathrm{C}\right)$, and when moving to cold regions, this coincidence is replaced by a complete contradiction. For birch, the decrease in leaf biomass as the climate increases in aridity coincides with a decrease in FE only in cold regions $\left(T_{m}=-30\right.$ to $\left.-40{ }^{\circ} \mathrm{C}\right)$, and as the transition to warm regions, this coincidence is replaced by a complete contradiction.

The patterns of biomass amount change under assumed changed climatic conditions (Figs. 2-4) are hypothetical. They reflect long-term adaptive responses of forest stands to regional climatic conditions and do not take into account rapid trends of current environmental changes, which place serious constraints on the ability of forests to adapt to new climatic conditions (Givnish, 2002, Berner et al., 2013, Schaphoff et al., 2016, Spathelf et al., 2018, Vasseur et al., 2018, DeLeo et al., 2020, Denney and Anderson, 2020). The law of limiting factors (Liebig 1840, Shelford 1913) works well in stationary conditions. With a rapid change in limiting factors (such as air temperature or precipitation), forest ecosystems are in a transitional (nonstationary) state, in which some factors that were still not significant may come to the fore, and the end result may be determined by other limiting factors (Odum, 1971, Du et al., 2019).

The main pool of our harvest data on forest biomass in Eurasia were obtained since 1970s to 1990s, and the climate maps used cover the period of the late 1990s and early 2000s. Some discrepancy between the two time periods may cause possible biases in the results obtained, but for such a small time difference in the initial data, the inclusion of compensatory mechanisms or phenological shifts in forest communities is unlikely (Anderegg et al., 2019, DeLeo et al., 2020). There is an uncertainty in assessing the impact of phenology on the biological productivity of stands, established for the cherry oak in the South of Russia: if the assessment of the biomass of oak stands did not reveal differences between the phenological varieties of oak, then the assessment of net primary production shows a 1.6-fold advantage of late-blooming variety over the early-blooming variety (Zhou Wen Nan, 1992).

Taking into account the stated methodological and conceptual uncertainties, the results presented in this study should be considered as preliminary ones. They can be modified if the biomass database will be enlarged by additional site-specific and stand-specific data. A full explanation for both the obtained regularities and counterintuitive results can be obtained after conducting detailed physiological studies.

\section{Conclusions}

A comparison of the reaction of pine and birch foliage biomass to changes in the average January temperature by $1^{\circ} \mathrm{C}$ at constant precipitation and average precipitation by $100 \mathrm{~mm}$ per year at constant temperature showed counterintuitive result. If low temperature and heavy precipitation are the limiting factors for pine leaf biomass, then low temperature and insufficient precipitation are the limiting factors for birch. When the temperature increases by $1^{\circ} \mathrm{C}$, the change in leaf biomass in pine, which is negative in dry conditions, becomes positive in wet conditions, and in birch, a positive change in dry conditions becomes negative in wet conditions. When precipitation increases by $100 \mathrm{~mm}$, the change in leaf biomass in pine trees that is negative in cold regions becomes positive in warm regions, and in birch trees, the positive change in leaf biomass in cold regions becomes negative in warm regions.

Hovewer, from the long-term perspective, climate change might bring even more drastic modification of winter temperature and annual sum of precipitation than was considered here. Therefore, our outputs represent just an example of model sensitivity to changing climatic conditions. The development of such a model for the main forest-forming species of Eurasia allow us to predict changes in the foliage productivity of the forest cover of Eurasia in relation to climate change.

\section{Declarations}




\section{Availability of data and materials}

The datasets used and/or analysed during the current study are available at: https://elar.usfeu.ru/handle/123456789/9648

\section{Ethics approval and consent to participate}

Not applicable.

\section{Consent for publication}

Not applicable.

\section{Competing interests}

The authors declare that they have no competing interests.

\section{Authors' contributions}

Vladimir Andreevich Usoltsev and Baozhang Chen participated in study design, data processing, interpreting the results and writing the manuscript. Peng Leng took part in the

\section{Acknowledgements}

This research was funded by the National Key R\&D Program of China (2017YFC0503904, 2018YFA0606001, 2017YFA0604302, and 2017YFA0604301), an international partnership program of Chinese Academy of Sciences (Grant 131A11KYSB20170025), a research project funded by the State Key Laboratory of Resources and Environmental Information System (088RA901YA) and a project funded by the National Natural Science Foundation of China (41771114 \& 41977404) as well as according to the programs of current scientific research of the Ural Forest Engineering University and Botanical Garden of the Ural Branch of Russian Academy of Sciences.

\section{References}

1. Abramova NT (1968) Types of wholeness and forms of regulation. In: Mathematical modeling of life processes. MF Vedenov etc. (eds.) Moscow, «Mysl'» Publishing: 168-183. (Rus.). https://www.studmed.ru/vedenov-mf-i-dr-redmatematicheskoe-modelirovanie-zhiznennyh-processov_8138d1dba66.html

2. Anderegg WRL, Anderegg LDL, Kerr KL, Trugman AT (2019) Widespread drought induced tree mortality at dry range edges indicates that climate stress exceeds species' compensating mechanisms. Glob Change Biol 25:3793-3802. https://doi.org/10.1111/gcb.14771

3. Ålvik G (1939) Über Assimilation und Atmung einiger Holzgewächse im westnorwegischen winter. Meddelelser fra Vestlandets Forstlige Forsöksstation Bergen 6(4):1-266

4. Anderson KJ, Allen AP, Gillooly JF, Brown JH (2006) Temperature-dependence of biomass accumulation rates during secondary succession. Ecol Lett 9:673-682. https://doi.org/10.1111/j.1461-0248.2006.00914.x

5. Baker M (2016) Is there a reproducibility crisis? Nature 533:452-454. https://doi.org/10.1038/533452a

6. Baskerville GL (1972) Use of logarithmic regression in the estimation of plant biomass. Can J For Res 2:49-53. https://doi.org/10.1139/x72-009

7. Behrensmeyer A (2006) Atmosphere. Climate change and human evolution. Science 311(5760):476-478. https://doi.org/10.1126/science.1116051 
8. Berner LT, Beck PSA, Bunn AG, Goetz SJ (2013) Plant response to climate change along the forest-tundra ecotone in northeastern Siberia. Glob Change Biol 19(11):3449-3462. https://doi.org/10.1111/gcb.12304

9. Bijak S (2010) Tree-ring chronology of silver fir and its dependence on climate of the Kaszubskie Lakeland (Northern Poland). Geochronometria 35: 91-94. https://doi.org 10.2478/v10003-010-0001-9

10. Bobrov EG (1978) Forest-forming conifers of the USSR. Leningrad, Nauka Publishing. (In Rus.)

11. Bocharnikov MV (2019) Bioclimate as a factor of the phytocenotic diversity's formation of the mountain taiga forests in the Stanovoy Highland. In: Forest ecosystems of boreal zone: Biodiversity, bioeconomy, ecological risks. Proc. of the AllRussian Conf. with Internat. Participation. Krasnoyarsk, August 26-31, 2019: 57-59. (In Rus.)

12. Boychenko AM (1970) Scots pine on the Northern growth limit in the Trans-Urals. Soviet Journal of Ecology 6:37-45 (in Rus.)

13. Cartellieri E (1935) Jahresgang von osmotischem Wert, Transpiration und Assimilation einiger Ericaceen der alpinen Zwergstrauchheide und von Pinus cembra. Jahrbuch für wissenschaftlich Botanik 82:460-506

14. Chernyshev VD (1974) Pathways of physiological and energetic adaptations of conifers under extreme conditions. In: Biologicheskie problemy Severa: Tezisy VI Simp. (Biological Problems of the North: Abstr. VI Symposium). Yakutsk: Inst. Biol., Yakutsk. Fil. Sib. Otd. Akad. Nauk SSSR, 5: 13-17 (in Rus.)

15. Denisov SA (2002) The role of birch in the formation of forest cover. Ecology Forests of the Volga Region 2:176-187 (in Rus. with English Abstract)

16. $10.1111 /$ gcb.14922

Denney DA, Anderson JT (2020) Natural history collections document biological responses to climate change: A commentary on DeLeo et al. (2019), Effects of two centuries of global environmental variation on phenology and physiology of Arabidopsis thaliana. Glob Change Biol 26: 340-342. https://doi.org/10.1111/gcb.14922

17. DeLeo VL, Menge DNL, Hanks EM, Juenger TE, Lasky JR (2020) Effects of two centuries of global environmental variation on phenology and physiology of Arabidopsis thaliana. Glob Change Biol 26(2):523-538.

https://doi.org/10.1101/424242

18. Draper N, Smith H (1966) Applied Regression Analysis. Wiley, New York

19. $10.3390 /$ rs 11161952

Du J, Watts JD, Jiang L, Lu H, Cheng X, Duguay C, Farina M, Qiu Y, Kim Y, Kimball JS, Tarolli P (2019) Remote sensing of environmental changes in cold regions: Methods, achievements and challenges. Remote Sens 11: 1952.

https://doi.org/10.3390/rs11161952

20. Eggers J, Lindner M, Zudin S, Zaehle S, Liski J (2008) Impact of changing wood demand, climate and land use on European forest resources and carbon stocks during the 21 st century. Glob Change Biol 14:2288-2303. https://doi.org/10.1111/J.1365-2486.2008.01653.X

21. Emanuel WR, Shugart HH, Stevenson MP (1985) Climate change and the broad scale distribution of terrestrial ecosystem complexes. Clim Change 7:29-43. https://doi.org/10.1007/bf00139439

22. Esslen J (1905) Das Gesetz des abnehmenden Bodenertrages seit Justus von Liebig: Eine dogmengeschichtliche Untersuchung. J. Schweitzer Verlag (Arthur Sellier), München

23. Ewart AJ (1896) On assimilatory inhibition. Bot J Linn Soc 31(217):364-461

24. Felton A, Nilsson U, Sonesson J, Felton AM, Roberge J-M, Ranius T, Ahlström M, Bergh J, Björkman C, Boberg J, Drössler L, Fahlvik N, Gong P, Holmström E, Keskitalo EC, Klapwijk MJ, Laudon H, Lundmark T, Niklasson M, Nordin A, Pettersson M, Stenlid J, Sténs A, Wallertz K (2016) Replacing monocultures with mixed-species stands: Ecosystem service implications of two production forest alternatives in Sweden. Ambio 45(Suppl 2):124-139.

https://doi.org/10.1007/s13280-015-0749-2

25. Folland CK, Palmer TN, Parker DE (2001) Climate change 2001: The scientific basis. In: Contribution of Working Group I to the Third Assessment Report of the Intergovernmental Panel on Climate Change (eds. JT Houghton et al), Cambridge University Press, Cambridge, UK

Page 13/19 
26. Forrester DI, Tachauer IHH, Annighoefer P, Barbeito I, Pretzsch H, Ruiz-Peinado R, Stark H, Vacchiano G, Zlatanov T, Chakraborty T, Saha S, Sileshi GW (2017) Generalized biomass and leaf area allometric equations for European tree species incorporating stand structure, tree age and climate. For Ecol Manag 396:160-175.

https://doi.org/10.1016/j.foreco.2017.04.011

27. Freeland RO (1944) Apparent photosynthesis in some conifers during the winter. Plant Physiol 19(2):179-185

28. Fu L, Sun W, Wang G (2017) A climate-sensitive aboveground biomass model for three larch species in northeastern and northern China. Trees 31:557-573. https://doi.org/10.1007/s00468-016-1490-6

29. Gernandt DS, López GG, García SO, Liston A (2005) Phylogeny and classification of Pinus. Taxon 54(1):29-42. https://doi.org/10.2307/25065300

30. Givnish TJ (2002) Adaptive significance of evergreen vs. deciduous leaves: solving the triple paradox. Silva Fenn 36:703743. https://doi.org/10.14214/sf.535

31. Glebov FZ, Litvinenko VI (1976) The dynamics of tree ring width in relation to meteorological indices in different types of wetland forests. Lesovedenie 4:56-62. (In Rus.)

32. Grimm GW, Renner SS (2013) Harvesting Betulaceae sequences from GenBank to generate a new chronogram for the family. Bot J Linn Soc 172:465-477. https://doi.org/10.1111/BOJ.12065

33. Guttinger S (2020) The limits of replicability. Eur J Philos Sci 10:10. https://doi.org/10.1007/s13194-019-0269-1

34. Halofsky JS, Conklin DR, Donato DC, Halofsky JE, Kim JB (2018) Climate change, wildfire, and vegetation shifts in a highinertia forest landscape: Western Washington. USA PLoS ONE 13(12):e0209490.

https://doi.org/10.1371/journal.pone.0209490

35. Han SH, Kim S, Li G, Chang H, Yun SJ, Jiae AJ, Son Y (2018) Effects of warming and precipitation manipulation on fine root dynamics of Pinus densiflora Sieb. et Zucc seedlings Forests 9(1):14. https://doi.org/10.3390/f9010014

36. Henrici M (1921) Zweigipfelige Assimilationskurven. Mit spezieller Berücksichtigung der Photosynthese von alpinen phanerogamen Schattenpflanzen und Flechten. Verhandlungen der Naturforschenden Gesellschaft in Basel 32:107-171

37. Huang J, Tardif JC, Bergeron Y, Denneler B, Berninger F, Girardin MP (2010) Radial growth response of four dominant boreal tree species to climate along a latitudinal gradient in the eastern Canadian boreal forest. Glob Change Biol 16:711-731. https://doi.org/10.1111/J.1365-2486.2009.01990.X

38. Hultén E (1937) Outline of the history of arctic and boreal biota during the Quaternary Period. New York, J. Cramer

39. Huston MA, Wolverton S (2009) The global distribution of net primary production: resolving the paradox. Ecol Monogr 79(3):343-377. https://doi.org/10.1890/08-0588.1

40. Hynynen J, Niemistö P, Viherä-Aarnio A, Brunner A, Hein S, Velling P (2010) Silviculture of birch (Betula pendula Roth and Betula pubescens Ehrh.) in northern Europe. Forestry 83(1):103-119. https://doi.org/10.1093/forestry/cpp035

41. Ioannidis JPA (2005) Why most published research findings are false. PLoS Med 2(8):e124.

https://doi.org/10.1371/journal.pmed.0020124

42. Ivanov L, Orlova I (1931) To the question about the winter photosynthesis of our coniferous. Zhurnal Russkogo Botanicheskogo Obshchestva 16(2-3):139-157 (in Rus.)

43. Iwanoff LA, Kossowitsch NL (1929) Über die Arbeit des Assimilationsapparates verschiedener Baumarten. I. Die Kiefer (Pinus silvestris). Planta (Berl 8:427

44. Jacobs MW, Cunia T (1980) Use of dummy variables to harmonize tree biomass tables. Can J For Res 10:483-490. https://doi.org/10.1139/x80-079

45. Jumelle MH (1892) Recherches physiologiques sur les lichens. 2. Influence de bases temperatures sur l'assimilation. Revue Générale de Botanique 4:305-320

46. Keeling HC, Phillips OL (2007) The global relationship between forest productivity and biomass. Glob Ecol Biogeogr 16:618-631. https://doi.org/10.1111/j.1466-8238.2007.00314.x 
47. Khan D, Muneer MA, Nisa Z-U, Shah S, Saeed S, Uddin S, Munir MZ, Lushuang G, Huang H (2019) Effect of climatic factors on stem biomass and carbon stock of Larix gmelinii and Betula platyphylla in Daxing'anling Mountain of Inner Mongolia, China. Adv Meteorol Article ID 5692574:1-10. https://doi.org/10.1155/2019/5692574

48. Khromov SP (1957) K voprosu o kontinental'nosti klimata (To a problem of climate continentality). Izvestiya Vsesoyuznogo Geograficheskogo Obshchestva 89(3):221-225. (In Rus.)

49. Kosanic A, Anderson K, Harrison S, Turkington T, Bennie J (2018) Changes in the geographical distribution of plant species and climatic variables on the West Cornwall Peninsula (South West UK). PLoS ONE 13(2):e0191021. https://doi.org/10.1371/journal.pone.0191021

50. Köstler JN, Brückner E, Bibelriether H (1968) Die Wurzeln der Waldbäume. Untersuchungen zur Morphologie des Waldbäume in Mitteleuropa. Verl. Paul Parey, Hamburg

51. Kramer PJ, Kozlovsky TT (1967) Physiology of Woody Plants. Academic Press, New York

52. Laing J, Binyamin J (2013) Climate change effect on winter temperature and precipitation of Yellowknife, Northwest Territories, Canada from 1943 to 2011. AJCC 2:275-283. https://www.scirp.org/journal/ajcc

53. Laitakari E (1935) The root system of birch (Betula verrucosa and odorata). Acta For Fenn 41:1-216 [in Finnish with English summary]

54. LaMarche VC (1974) Paleoclimatic inferences from long tree-ring records: Intersite comparison shows climatic anomalies that may be linked to features of the general circulation. Science 183:1043-1048. https://doi.org/10.1126/science.183.4129.1043

55. Lapenis A, Shvidenko A, Shepaschenko D, Nilsson S, Aiyyer AR (2005) Acclimation of Russian forests to recent changes in climate. Glob Chang Biol 11:2090-2102. https://doi.org/10.1111/J.1365-2486.2005.001069.X

56. Lepekhin II (1780) Daily notes of the journey of doctor and associate of the Academy of Sciences Ivan Lepekhin to different provinces of the Russian state in 1771. Parts 3. Saint Petersburg, Imperial Academy of Sciences. (In Rus.). https://runivers.ru/lib/book7645/

57. Levanič T, Poljanšek S, Toromani E (2015) Early summer temperatures reconstructed from black pine (Pinus nigra Arnold) tree-ring widths from Albania. Holocene 25(3):469-481. https://doi.org/10.1177/0959683614561882

58. Liebig J (1840) Organic chemistry in its application to agriculture and physiology. Braunschweig. In: German Text Archive < http://www.deutschestextarchiv.de/liebig_agricultur_1840>, accessed on May 22, 2020.

59. Lyr H, Polster H. Fiedler HJ (1967) Gehölzphysiologie. VEB Gustav Fisher Verlag, Jena

60. Mamaev S (1983) Types of coniferous in the Urals and their use in planting of greenery. Sverdlovsk: Institute of Plants and Animals Ecology of the Ural Scientific Centre of the Academy of Sciences of the USSR. (In Rus.)

61. Matthaei GLC (1902) The effect of temperature on carbon dioxide assimilation. Ann Bot 16:591-593. https://doi.org/10.1093/oxfordjournals.aob.a088895

62. Miles-Novelo A, Anderson CA (2019) Climate change and psychology: Effects of rapid global warming on violence and aggression. Current Climate Change Reports 5:36-46. https://doi.org/10.1007/s40641-019-00121-2

63. Molchanov AA (1971) Productivity of organic mass in the forests of different zones. "Nauka" Publishing House, Moscow. (In Rus.)

64. Molchanov AA (1976). Dendro-climatic fundamentals of weather forecasts. Moscow, Nauka Publ. (in Rus.)

65. Morley JW, Batt RD, Pinsky ML (2017) Marine assemblages respond rapidly to winter climate variability. Glob Change Biol 23:2590-2601. https://doi.org/10.1111/gcb.13578

66. Odum EP (1971) Fundamentals of Ecology. The third Edition. W.B. Saunders Company, Philadelphia-London-Toronto

67. Olsen N, Mandea M (2007) Will the Magnetic North Pole move to Siberia? Eos Trans AGU 88(29):293-300. https://doi.org/10.1029/2007EO290001

68. Ostonen I, Lõhmus K, Helmisaari H-S, Truu J, Meel S (2007) Fine root morphological adaptations in Scots pine, Norway spruce and silver birch along a latitudinal gradient in boreal forests. Tree Physiol 27:1627-1634.

Page 15/19 
https://doi.org/10.1093/TREEPHYS/27.11.1627

69. Paquette A, Vayreda J, Coll L, Messier C, Retana J (2018) Climate change could negate positive tree diversity effects on forest productivity: A study across five climate types in Spain and Canada. Ecosystems 21(5):960-970.

https://doi.org/10.1007/s10021-017-0196-y

70. Perov VF (2008) The growth and stability of natural island-like forests of silver birch in the dry steppe on sandi soils near Yeruslan river. In: Modern problems of theory and practice of forestry. E. M. Romanov (ed.). Yoshkar-Ola, Mari State Technical University: $158-160$

71. Pisek A (1960) Immergrüne Pflanzen. Handbuch der Pflanzenphysiologie. Bd. V/2. Berlin-Göttingen-Heidelberg, Springer

72. Pisek A, Rehner G (1958) Temperaturminima der Netto-Assimilation von mediterranen und nordisch-alpinen Immergrünen. Ber Dtsch Bot Ges 71(4):188-193

73. Poudel BC, Sathre R, Gustavsson L, Bergh J, Lundström A, Hyvönen R (2011) Effects of climate change on biomass production and substitution in north-central Sweden. Biomass Bioenerg 35(10):4340-4355. https://doi.org/10.1016/J.BIOMBIOE.2011.08.005

74. Printz H (1933) Granenes og furuens fysiologi og geografiske utbredelse. Nyt Magazin for Naturvidensk 73:167-219

75. Röhle H, Gerold D, Gemballa R (2010) Beziehungen zwischen Klima und Zuwachs, dargestellt am Beispiel von Fichte, Kiefer und Buche in Sachsen. Allg. Forst- $\mathrm{u} J-Z \operatorname{tg}$ 181(1/2):21-35

76. Rozenberg GS, Ryansky FN, Lazareva NV, Saksonov SV, Simonov YuV, Khasaev GR (2016) Common and Applied Ecology. Samara State University of Economics Press, Samara-Togliatti. (In Rus.)

77. Schaberg PG, Wilkinson RC, Shane JB, Donnelly JR, Cali PF (1995) Winter photosynthesis of red spruce from three Vermont seed sources. Tree Physiol (15): 345-350. https://doi.org/10.1093/treephys/15.5.345

78. Schaphoff S, Reyer CPO, Schepaschenko D et al (2016) Tamm review: Observed and projected climate change impacts on Russia's forests and its carbon balance. For Ecol Manag 361:432-444.

https://doi.org/10.1016/J.FOREC0.2015.11.043

79. Schulze ED, Mooney HA (1994) Biodiversity and Ecosystem Function. Springer-Verlag, Berlin

80. Shelford VE, Metcalf C (1913) Animal communities in temperate America, as illustrated in the Chicago region; a study in animal ecology. The Geographic Society of Chicago Bulletin, 13 (5)

81. Shuman JK, Shugart HH (2009) Evaluating the sensitivity of Eurasian forest biomass to climate change using a dynamic vegetation model. Environ Res Lett 4 (4): 1-7. https://doi.org/ 10.1088/1748-9326/4/4/045024

82. Smashevskiy ND (2014) Ecology of photosynthesis. Astrakhanskiy Vestnik Ekologicheskogo obrazovania. (Astrakhan Bulletin of Environmental Education) 2(28):165-180. (In Rus.)

83. Spathelf P, Stanturf J, Kleine M et al (2018) Adaptive measures: Integrating adaptive forest management and forest landscape restoration. Ann For Sci 75(2): 55. https://doi.org/ 10.1007/s13595-018-0736-4

84. Stafasani M, Toromani E (2015) Growth-climate response of young Turkey oak (Quercus cerris L.) coppice forest stands along longitudinal gradient in Albania. South-East Eur For 6 (1): 25-38. https://doi.org/ 10.15177/SEEFOR.15 - 05

85. Stegen JC, Swenson NG, Enquist BJ, White EP, Phillips OL, Jorgensen PM, Weiser MD, Mendoza AM, Vargas PN (2011) Variation in aboveground forest biomass across broad climatic gradients. Global Ecol Biogeogr 20:744-754. http://dx.doi.org/10.1111/j.1466-8238.2010.00645.x

86. Strömgren M, Linder S (2002) Effects of nutrition and soil warming on stem wood production of a boreal Norway spruce stand. Global Change Biol 8:1195-1204. http://dx.doi.org/10.1046/J.1365-2486.2002.00546.X

87. Tolmachev Al (1962) Osnovy ucheniya ob arealakh: Vvedenie v khorologiyu rasteniy (Fun-damentals of Plant Habitat Theory: Introduction to Plant Community Chorology), Leningrad, State University Publishing. (In Rus.)

88. Toman MA, Firor J, Darmstadter J (1996) Climate Change and Its Consequences. RFF 124:10-13

89. Toromani E, Bojaxhi F (2010) Growth response of silver fir and Bosnian pine from Kosovo. South-East Eur For 1:20-28. http://dx.doi.org/10.15177/seefor.10-03

Page 16/19 
90. Taylor WP (1934) Significance of extreme or intermittent conditions in distribution of species and management of natural resources, with a restatement of Liebig's law of the minimum. Ecology 15:274-379

91. Usoltsev VA (2003) Forest biomass of Northern Eurasia: the limits of productivity and their geography. Yekaterinburg, Ural Branch of Russian Academy of Sciences. (In Rus.). http://elar.usfeu.ru/handle/123456789/3303

92. Usoltsev V (2007) Some methodological and conceptual uncertainties in estimating the in-come component of the forest carbon cycle. Rus J Ecol 38(1):1-10. http://dx.doi.org/10.1134/S1067413607010018

93. Usoltsev VA (2019) Forest Arabesques, or Sketches of Our Trees' Life. The 3rd Edition, modified. Radomska Szkoła Wyższa w Radomiu. Radom, Poland. http://dx.doi.org/ 10.5281/zenodo.2551187

94. Usoltsev VA (2020) Forest biomass and primary production database for Eurasia: digital version. The third edition, enlarged. Yekaterinburg, Ural State Forest Engineering University. https://elar.usfeu.ru/handle/123456789/9648

95. Usoltsev VA, Shobairi SOR, Chasovskikh VP (2018) Foliage productivity in Eurasian forests as related to climatic variables. Discovery Nature 12:91-101

96. 10.1073/pnas.1709141115

Vasseur F, Exposito-Alonso M, Ayala-Garay OJ, Wang G, Enquist BJ, Vile D, Violle C, Weigel D (2018) Adaptive diversification of growth allometry in the plant Arabidopsis thaliana. Proc. Natl. Acad. Sci. USA 115: 3416-3421. http://dx.doi.org/10.1073/pnas.1709141115

97. Wieser G (1997) Carbon dioxide gas exchange of cembran pine (Pinus cembra) at the alpine timberline during winter. Tree Physiol 17:473-477. http://dx.doi.org/10.1093/treephys/17.7.473

98. Wilmking M, Juday GP, Barber VA, Zald HSJ (2004) Recent climate warming forces contrasting growth responses of white spruce at tree line in Alaska through temperature thresholds. Glob Change Biol 10:1724-1736.

http://dx.doi.org/10.1111/j.1365-2486.2004.00826.x

99. World Weather Maps (2007) https://www.mapsofworld.com/referrals/weather/

100. Xu C, Kohler TA, Lenton TM, Svenning J-C, Scheffer M (2020) Future of the human climate niche. PNAS USA 117(21):11350-11355. https://doi.org/10.1073/pnas.1910114117

101. Zacharowa TM (1929) Über den Gasstoffwechsel der Nadelholzpflanzen im winter. Planta 8(1/2):68-83

102. Zalesov SV, Kryazhevskikh IA, Luganskiy N (1994) Component dynamics of the litter of bog pine forests and return of mineral elements with plant litter. Lesa Urala i khozyaistvo v nikh 17:102-111 (in Rus.)

103. Zeller L, Liang J, Pretzsch H (2018) Tree species richness enhances stand productivity while stand structure can have opposite effects, based on forest inventory data from Germany and the United States of America. For Ecosyst 5:4. https://doi.org/10.1186/s40663-017-0127-6

104. Zeller O (1951) Über Assimilation und Atmung der Pflanzen im winter bei tiefen Temperaturen. Planta 39:500-526

105. Zhou WN (1992) Phytomass and features of nitrogen and ash elements cycling in the ecosystems of the cherry oak of various phenological varieties in the conditions of the Central Chernozem region. PhD Thesis. Voronezh, Voronezh Forest Engineering Institute. 23 p. (in Rus.)

106. Zhou P, Ang BW, Poh KL (2008) A survey of data envelopment analysis in energy and environmental studies. Eur J Oper Res 189:1-18. https://doi.org/10.1016/j.ejor.2007.04.042

107. Zubairov B, Heußner K-U, Schröder H (2018) Searching for the best correlation between climate and tree rings in the Trans-lli Alatau. Kazakhstan Dendrobiology 79:119-130. http://dx.doi.org/10.12657/denbio.079.011

\section{Figures}




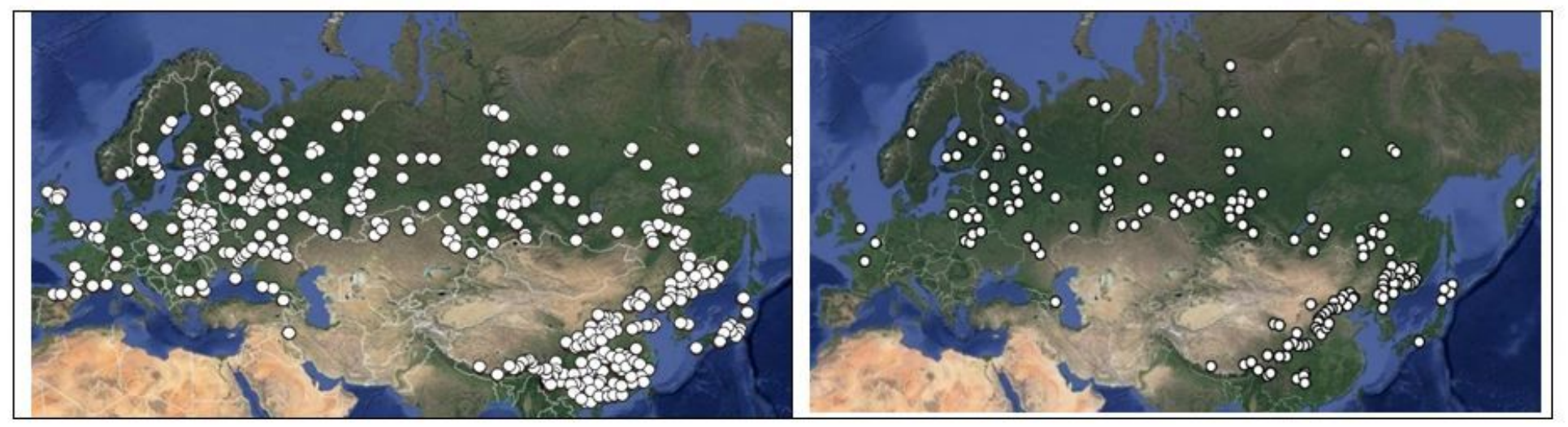

Figure 1

The distribution of 2,110 sampling sites of Pinus (left hand side) and 510 sampling sites of Betula (right hand side) on the territory of Eurasia.
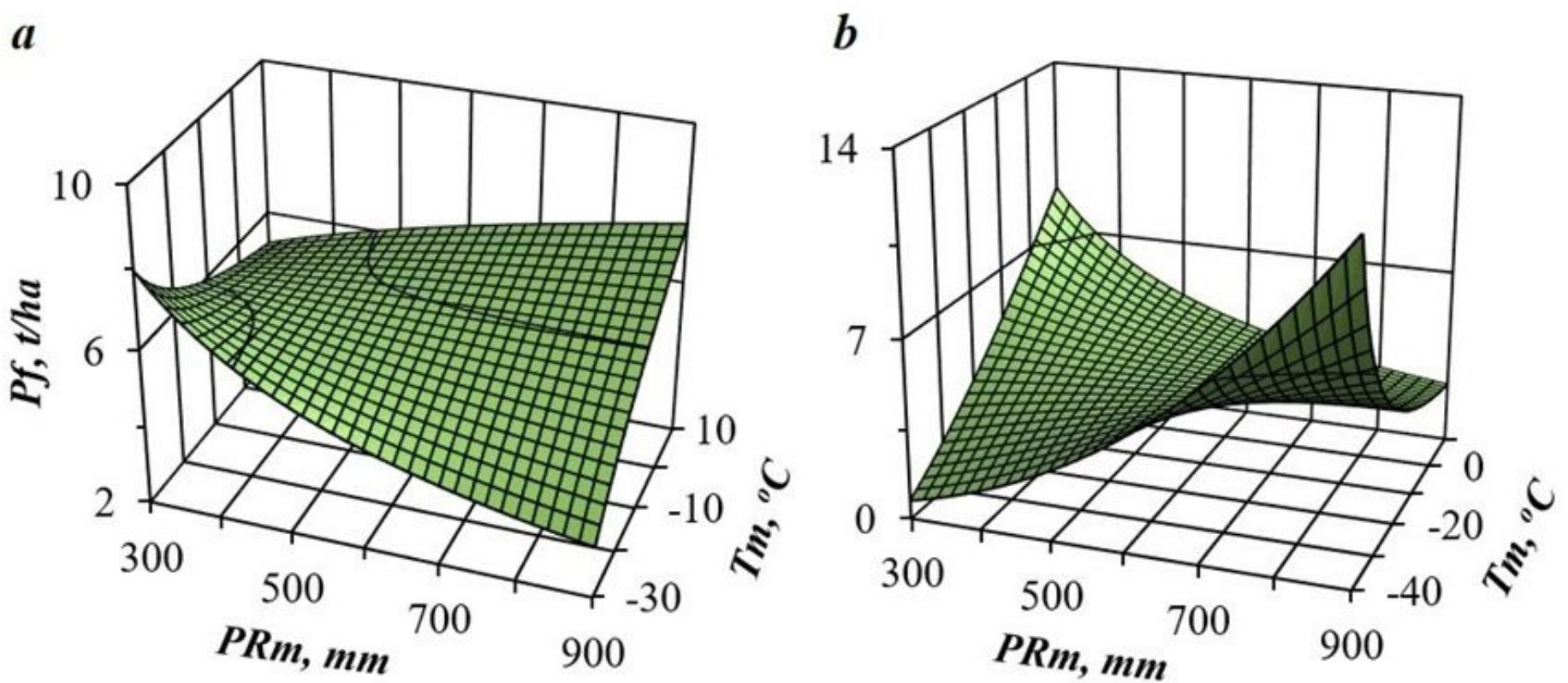

Figure 2

Dependence of pine $a$ and birch $b$ forest biomass (Pf) of Eurasia upon the mean January temperature (Tm) and mean annual precipitation (PRm). 

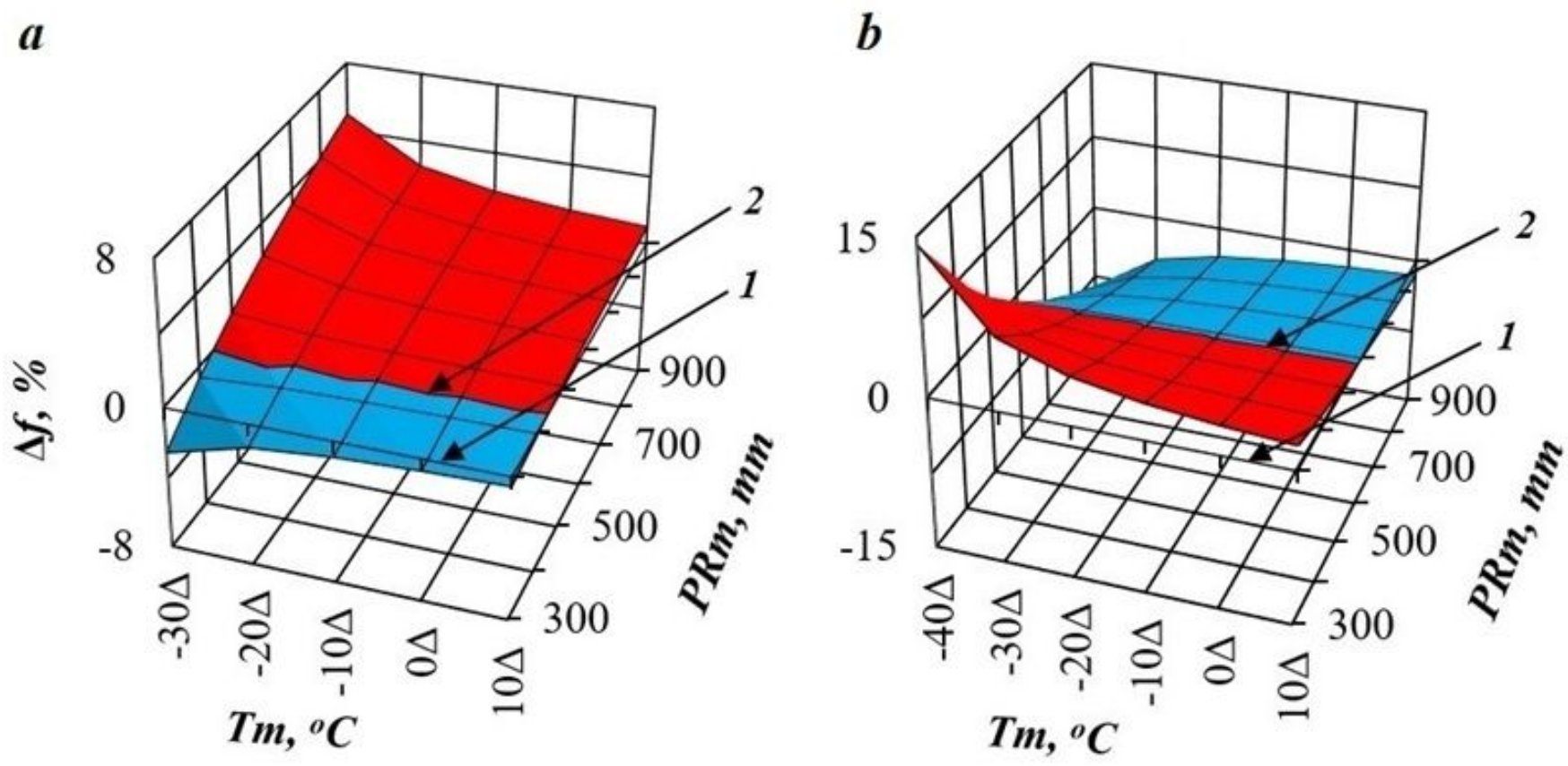

Figure 3

Simulated changes in pine a and birch foliage biomass due to temperature increase of $1^{\circ} \mathrm{C}$ based on the derived model (for the stands aged 100 years). Here the value 1 represents the plane corresponding to zero change of biomass at the expected temperature increase by $1^{\circ} \mathrm{C}$; the value 2 represents the border between positive and negative changes in biomass $(\Delta, \%)$ at the expected temperature increase by $1^{\circ} \mathrm{C}$.
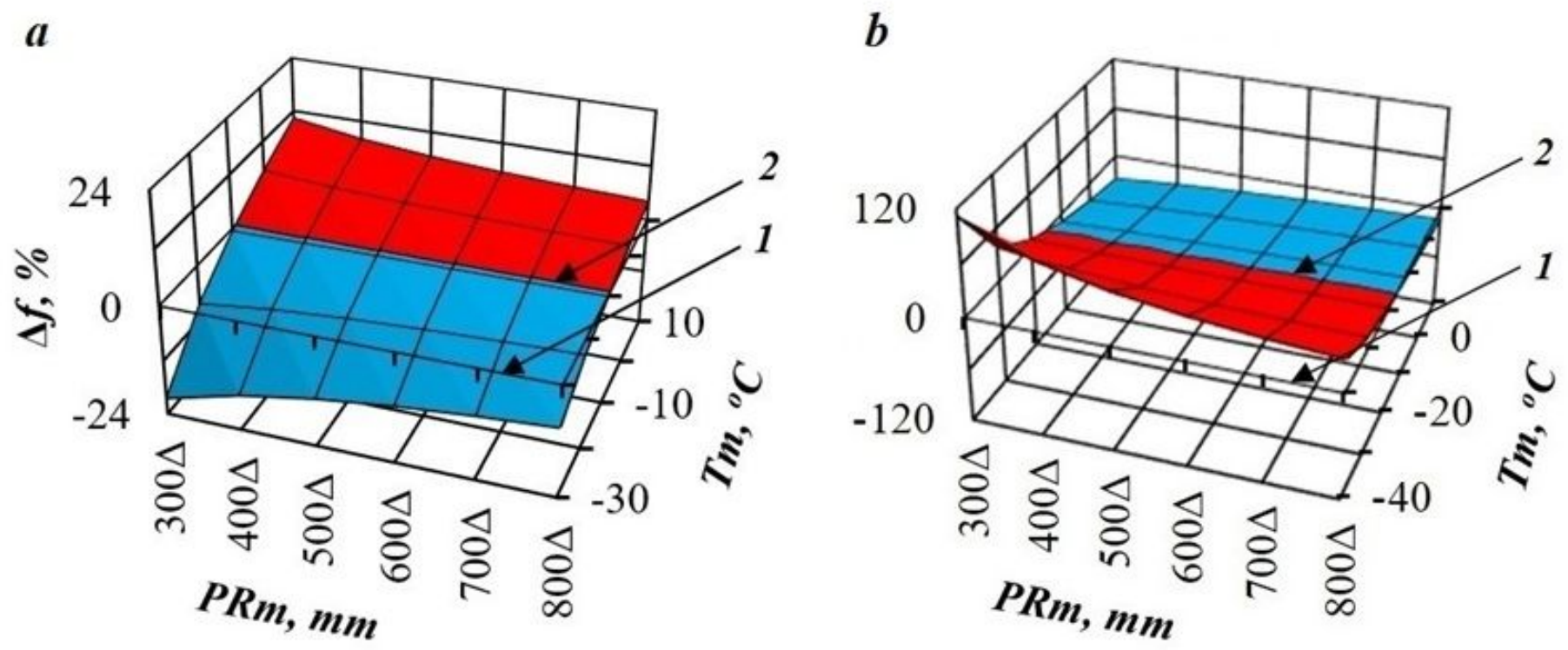

Figure 4

Simulated changes in pine $a$ and birch $b$ foliage biomass due to the assumed precipitation increase of $100 \mathrm{~mm}$ (for the stands aged 50 years). 